\title{
A New Species of the Genus Burmoniscus (Isopoda, Oniscidea, Philosciidae) from Ko Phuket, Thailand
}

\author{
Dae Soo Jeon and Do Heon Kwon* \\ School of Biological Sciences, Inje University, Kimhae 621-749, Korea
}

\begin{abstract}
A new species, Burmoniscus phuketensis, is described from Ko Phuket, Thailand. The new species belongs to the group characterized by male pereopods 1 and 2 with enlarged and flattened carpi, including $B$. coecus (Budde-Lund, 1895), B. ferrarai (Schumalfuss, 1983), B. mossambicus (Ferrara and Taiti, 1985), B. rowei Taiti and Manicastri, 1988, and B. rakataensis Green, Ferrara and Taiti, 1990. Among them, this new species resembles $B$. coecus and $B$. rakataensis in the pigmentless body and the shape of pereonite 7 epimeron with acute postero-lateral corner, but is easily distinguished from both specie by the shape of telson. While the eyes are absent in B. coecus, they are present in this new species.
\end{abstract}

Key words: Oniscidea, Philosciidae, Burmoniscus phuketensis, new species, Thailand

\section{INTRODUCTION}

The genus Burmoniscus Collinge, 1914 belongs to oniscidean family Philosciidae and includes more than seventy species which are distributed in tropical and subtropical zones of Ethiopian, Oriental and Australian Regions.

Thailand, as well as the other parts of Southeast Asia, is one of the regions that have had very little attention in the field of terrestrial isopods. Among the species in the genus Burmoniscus, only three species, B. orientalis Green, Ferrara and Taiti, 1990, B. siamensis Jeon and Kwon, 2001, and B. phanganensis Jeon and Kwon, 2001, have been previously recorded from Thailand (Green et al., 1990; Jeon and Kwon, 2001). This paper deals with a new species of Burmoniscus collected from Ko Phuket, the largest island of Thailand located in the Andaman Sea. It is described with figures of the diagnostic characters.

The specimens examined are deposited in the National Institute of Biological Resources, Incheon (NBR) and the School of Biological Sciences, Inje University, Kimhae(IJB).

\section{SYSTEMATIC ACCOUNT}

Genus Burmoniscus Collinge, 1914

Synonyms: Burmoniscus Collinge, 1914: 466.

Formososcia Verhoeff, 1928: 218.

Rennelloscia Vandel, 1970: 143.

Vavoscia Schultz, 1985: 216.

\footnotetext{
*To whom correspondence should be addressed

Tel: 82-55-320-3214, Fax: 82-55-336-7706
}

E-mail: biodhkwo@inje.ac.kr
Type species: Burmoniscus moulmeinus Collinge, 1914 (=Philoscia coeca Buddel-Lund, 1895) by original monotypy.

\section{Burmoniscus phuketensis sp. nov. (Figs. 1-3)}

Material examined. Holotype: $\sigma^{\top}$, body length $4.7 \mathrm{~mm}$, Phuket, Ko Phuket, Ao Kata Yai, 26.VI.1993, leg. D.H. Kwon (NBR). Paratypes: 2 『 శ, 2 우 우, same data as holotype (NBR); 3 ๙, 1 우, same data (IJB).

Description. Maximum length of male $4.7 \mathrm{~mm}$, of female $4.8 \mathrm{~mm}$. Body pigmentless. Dorsum smooth with sparse setae. A few gland pores at antero-lateral corners of pereonal epimera 1, 6 and 7; no gland pores at pereonal epimera 2-5. Each pereonite with a nodulus lateralis per side; noduli laterales on pereonites 2, 4 and 7 much farther from lateral margin than those on the other pereonites. Eye with 4 (rarely 3) ommatidia. Cephalon about twice as wide as long; supra-antennal line bent down in middle; frontal line absent. Pereonite 7 epimeron with postero-lateral corner acutely angled. Pleonal epimera reduced, with short postero-lateral points on pleonites 3-5, not visible in dorsal view. Telson with outer-distal sides almost straight and triangular apex protruding posteriorly. Antennule three-articulated with third article bearing 2 rows of aesthetascs on inner margin and 2 long ones at apex. Antenna with fifth article of peduncle slightly longer than flagellum; flagellum three-articulated with second and third articles bearing 4 and 2 aesthetascs respectively; length ratio of flagellar articles $8: 6: 7$. Mandible with a molar penicil consisting of a single plumose seta. Maxillule with exopod bearing 4+6 (5 cleft) teeth on distal margin; endopod bearing two unequal peni- 

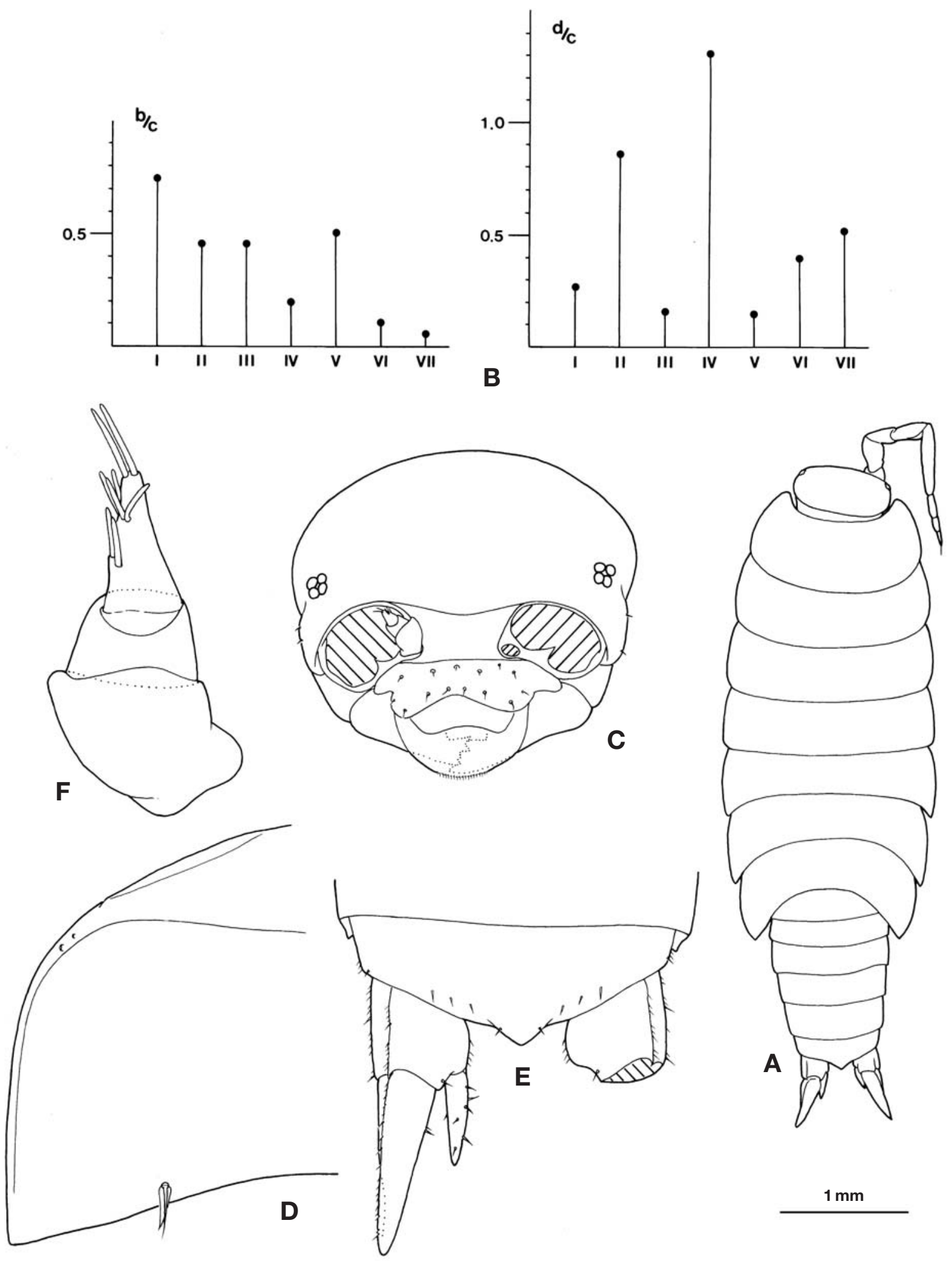

Fig. 1. Burmoniscus phuketensis, sp. nov., paratype female: A, habitus; B, co-ordinates of noduli laterales (b, distance of nodulus lateralis from the posterior margin of pereonite; $c$, length of pereonite; $d$, distance of nodulus lateralis from the lateral margin of pereonite); C, cephalon, frontal view; $D$, left epimeron of pereonite 7; E, pleonite 5, telson and uropods; $F$, antennule. 


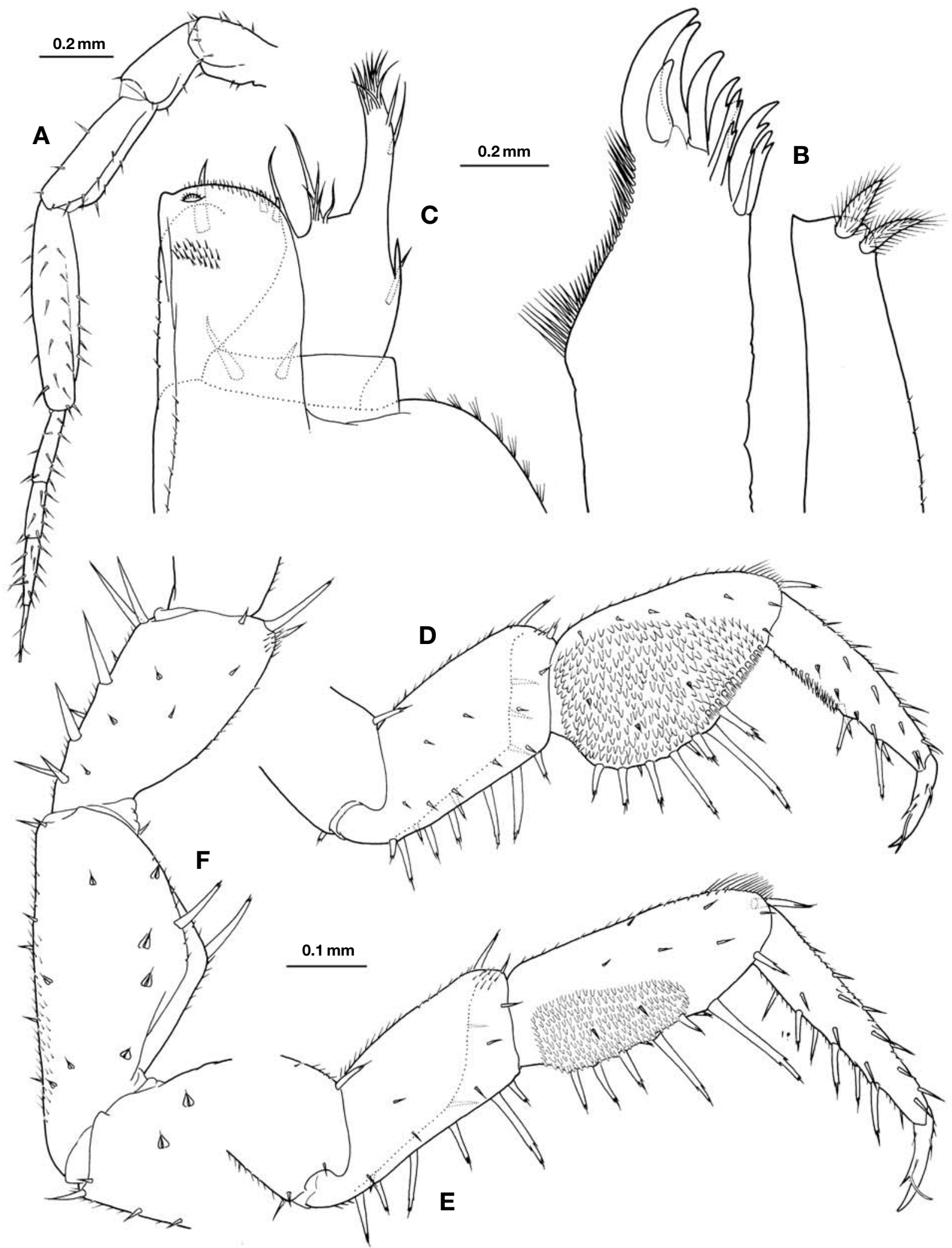

Fig. 2. Burmoniscus phuketensis, sp. nov., A and D-F, paratype male; $B, C$, paratype female: $A$, antenna; $B$, maxillule; $C$, maxilliped; $D$, pereopod $1 ; E$, pereopod $2 ; F$, pereopod 7 ischium and merus. 

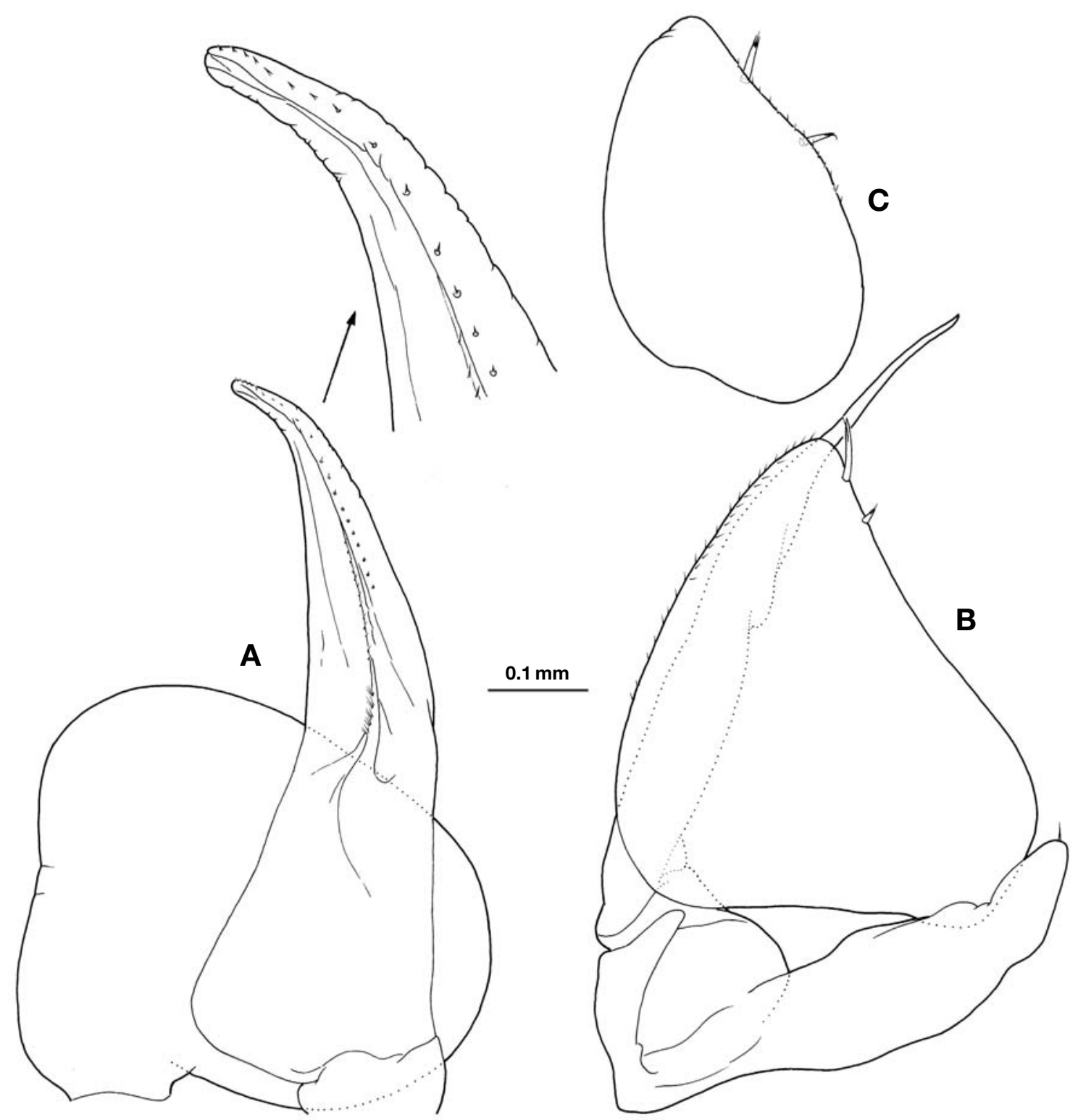

Fig. 3. Burmoniscus phuketensis, sp. nov., paratype male: A, pleopod 1; B, pleopod 2; C, pleopod 5 exopod.

cils and an acute outer-distal point well-developed. Endite of maxilliped with a penicil. Uropodal protopod grooved on outer margin; insertion of endopod proximal to that of exopod; exopod about twice as long as endopod.

Male. Pereopod 1, and to a lesser extent, 2 with carpi enlarged, flattened and covered with numerous setules on rostral surface. Pereopod 7 without sexual modification; ischium with sternal margin almost straight. Pleopod 1 exopod wider than long with posterior point broadly rounded; endopod with distal part clearly bent outwards. Pleopod 2 exopod longer than wide with outer-distal margin slightly concave; endopod with distal part slender, distinctly longer than exo- pod. Pleopod 5 exopod as in Fig. 3C.

Etymology. The specific name refers to Phuket, the type locality of this new species.

Remarks. Burmoniscus phuketensis, sp. nov. belongs to the group of Burmoniscus characterized by male pereopods 1 and 2 with enlarged and flattened carpi. B. coecus (Budde-Lund, 1895) from Myanmar, B. ferrarai (Schumalfuss, 1983) from Nepal, B. mossambicus (Ferrara and Taiti, 1985) from Mozambique, B. rowei Taiti and Manicastri, 1988 from Sri Lanka, and B. rakataensis Green, Ferrara and Taiti, 1990 from Krakatau I. are included in this group.

Among them, this new species resembles B. coecus and 
B. rakataensis for the pigmentless body and the shape of pereonite 7 epimeron with acute postero-lateral corner, but is easily distinguished from both of them by the shape of telson. While the eyes are absent in B. coecus, they are present in this new species.

\section{ACKNOWLEDGEMENTS}

This work was supported by grant from Inje University, 2002.

\section{REFERENCES}

Collinge, W.E., 1914. Zoological results of the Abor Expedition, 1911-1912. Terrestrial Isopoda. Rec. Indian Mus., 8(6): 465469, pls. 31-33.
Green, A.J.A., F. Ferrara and S. Taiti, 1990 Terrestrial Isopoda from the Krakatau Islands, South Sumatra and West Jaya. Mem. Mus. Vict., 50(2): 417-436.

Jeon, D.S. and D.H. Kwon, 2001. Two new species of the genus Burmoniscus (Isopoda, Oniscidea, Philosciidae) from Ko Samui and Ko Pha Ngan, Thailand. Korean J. Syst. Zool., 17: 145-153.

Schultz, G.A., 1985. Three terrestrial isopod crustaceans from Java, Indonesia (Oniscoidea, Philosciidae). J. Nat. Hist., 19: 215-223.

Vandel, A., 1970. Les Isopodes terrestres des îles Rennell et Bellona. In Wolff, T. ed., The natural history of Rennell Island, British Solomon Islands, 6: 139-153.

Verhoeff, K.W., 1928. Isopoden aus Formosa. 39. IsopodenAufsatz. Mitt. Zool. Mus. Berlin, 12: 200-226.

Received June 18, 2009 Accepted June 24, 2009 